\title{
Om pottemagere og kakler fra Christiansfeld
}

\section{Af Ebbe Johannsen.}

Blandt sønderjyske antikviteter indtager kaklerne fra Christiansfeld en ganske særlig plads.

Når der her anvendes ordet kakkel, bruges det i den $x$ ldre betydning, nemlig som betegnelse for de keramikstykker, hvoraf man opbyggede kakkelovne, og det har altså ikke noget at gøre med de meget almindelige dekorerede fliser, der populært benævnes kakler.

Kaklerne var of test glaserede på forsiden og havde bagtil en bred ramme, så de kunne mures op over hinanden.

Det var pottemageren, som lavede dem.

Kakkelovne opbyggede af sådanne kakler var i en lang periode en højt værdsat specialitet for herrnhuterbyen Christiansfeld - som honningkager og pølser er det i dag.

Kaklerne er ikke alene - især for de ældre typers vedkommende - af fortræffelig kvalitet, men de ældre kakler har også et iøjnefaldende særpræg, der gør, at de egentlig ikke ligner noget andet keramik fra den danske konges lande. Man finder dem ikke alene i herrnhuterbyen og dens omegn; deres forekomst langt fra Christiansfeld vidner om, hvor efterspurgte Christiansfelder-ovnene engang har været.

Ligesom den bevægelse, der skabte Christiansfeld, strengt bevarede sit religiøse særpræg, hvor den end forekom, således var også erhvervslivet $\mathrm{i}$ brødremenighedens kolonier underlagt en nøje uniformering, og det må som alle andre foreteelser indenfor menigheden anskues $i$ en større sammenhæng.

For at forstå baggrunden for kakkelovnsfremstillingen i Christiansfeld er det nødvendigt at se på forholdene $i$ den herrnhuterkoloni, der fandtes i Neuwied am Rhein i Tyskland. Her modtog den tolerante greve Johann Alexander af Wied i 1750 den lille fordrevne herrnhutermenighed fra Herrnhaag i Wetterau.

Brødremenigheden stammer fra det 15. århundrede, da Johan Hus i Böhmen stiftede menigheden i reaktion mod katolicismen. Det var dog først $\mathrm{i}$ det 18 . århundrede, at den skulle opleve en blomstring, 
der bl. a. skulle få grundlæggelsen af Christiansfeld til følge. 13. august 1727 er stiftelsesdagen for "den fornyede brødrekirke " i Herrnhut ikke langt fra Dresden.

Herrnhuterne betragtede et falles, inderligt kirkeliv med en streng kirketugt som en nødvendig livsbetingelse, og deres byer blev til efter en nøje plan med menighedslivet for øje. Men da også arbejdsomhed og dygtighed $\mathrm{i}$ borgerlige erhverv hørte med til dagliglivet i disse byer, blomstrede de op på en måde, som tiltvang dem almindelig respekt og gjorde, at man fra øvrighedens side kunne se med velvilje på oprettelsen af nye kolonier, som tilfældet var herhjemme.

Her skal ikke gøres rede for bevægelsens indhold. Det er for nyligt blevet gjort af A. Pontoppidan Thyssen i Vækkelsernes frembrud i Danmark, IV, 1967, blot skal det slås fast, at herrnhuterne i virkeligheden - om ikke åbenlyst - tilsigtede et religiøst og borgerligt idealsamfund med teokratisk ledelse af alle forhold - fra erhvervsliv til børneavl - og vidtgående psykologisk og ideologisk ensretning.

I Neuwied fik den indvandrede menighed snart bygget de huse, som trossamfundet havde brug for, og de kom til at udgøre et sarligt kvarter $i$ byen.

I brødrehuset boede de ugifte mandlige menighedsmedlemmer i næsten klosteragtig isolation, og der fik de deres opdragelse og uddannelse. De forskellige erhverv blev fra begyndelsen af drevet af menigheden og ikke som privaterhverv, selv om mange af dem senere gik over $i$ privat eje.

De udøvedes i det rummelige brødrehus eller på dets grund, og her tog også pottemageriet i 1758 sin begyndelse. Det var dog først, efter at pottemagermesteren Erich Berg var blevet hidkaldt fra Herrnhut i Sachsen, at den udvikling tog fart, der skulle fore til oprettelsen af søsterforetagendet i Christiansfeld.

Erich Berg stammede fra Nerke i Sverige, hvor han havde lært professionen. Han døde imidlertid allerede i 1760, og efter at et par andre havde arbejdet som mestre, blev Abraham Goll i 1770 leder af pottemageriet.

Abraham Goll var født 15. marts 1736 ved Zürich i Svejts og kom 1759 til Neuwied, hvor han samme år er at trxffe $i$ pottemagerstuen i brødrehuset. Han virkede som mester fra 1770 til 1777, da han forsvinder og afloses af en anden. 


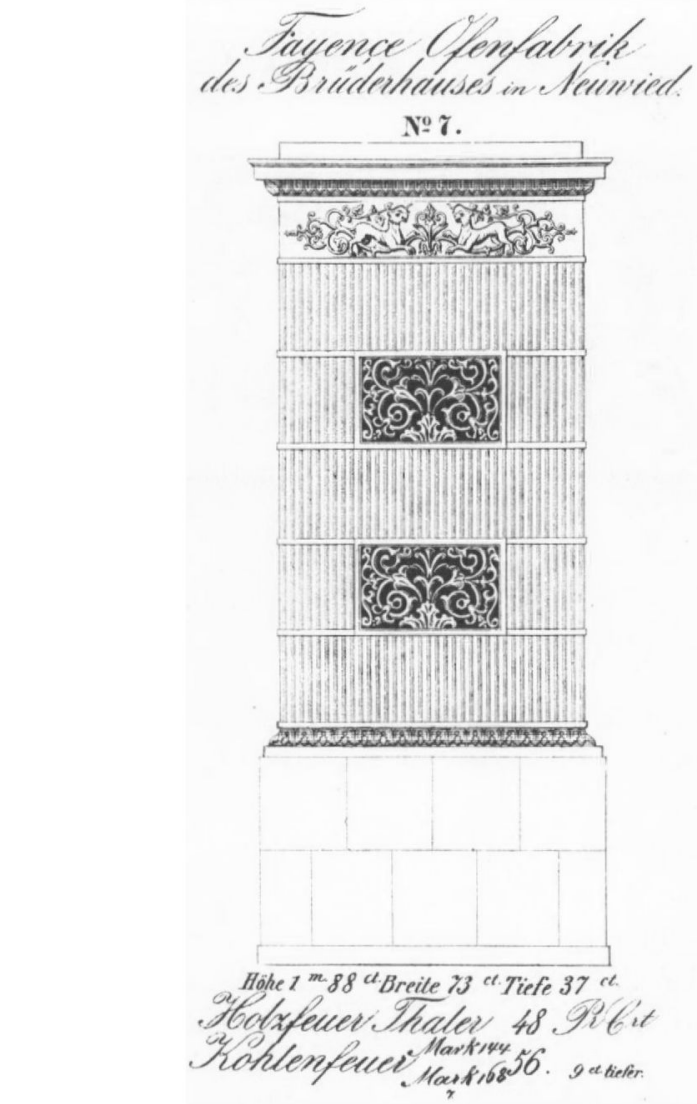

Biedermeierovn fra Fayence Ofenfabrik des Brüderhauses $i$ Neuwied. Katalogbillede. Privateje.

Hvad der senere blev af Abraham Goll, skal vi i det følgende komme ind på.

Allerede fra begyndelsen gav pottemageriet sig af med fremstillingen af kakkelovne. De blev snart dets egentlige specialitet, og herrnhuter-kakkelovne blev med tiden et begreb, der var kendt viden om.

De tidligste ovne fra Neuwied har simple blyglasurer, men snart skete der en omstilling til fajanceovne med hvid glasur.

Fra bevarede eksemplarer og billeder kender vi nogle af disse tidlige ovne. Katalogillustrationer viser os således fabrikkens noble Biedermeier-ovne, der enten var glatte eller riflede og prydet med 


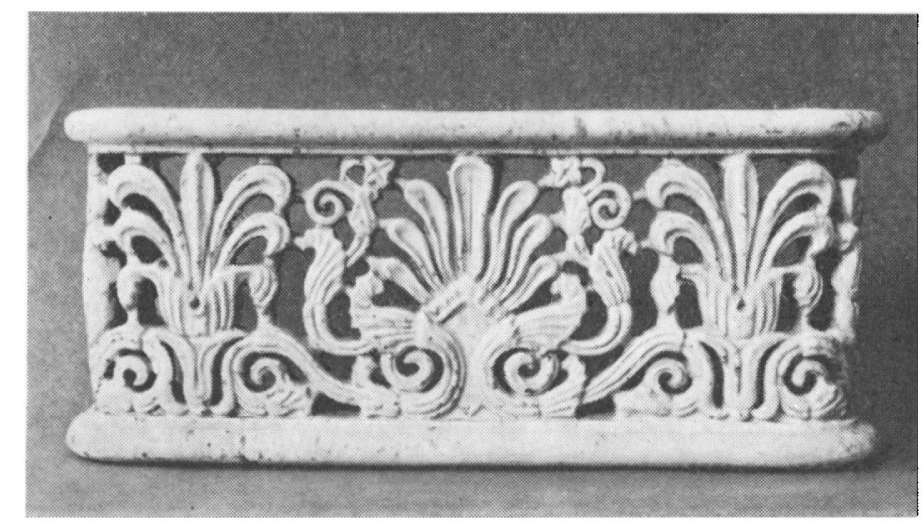

Biedermeier-kakkel i gennembrudt arbejde. Stanket, lys brunviolet glasur med gronligt skar. Hojde ca. $15 \mathrm{~cm}$. Privateje.

en smagfuld senklassicistisk ornamentik. Der er unxgtelig et smagsmæssigt svælg mellem disse ovne og fabrikkens senere produkter, hvorpå dekorationen kom til at bestå af allehånde uglaserede relieffer i stilløs forvirring - som tiden krævede det - og hyppigt af et særdeles bombastisk germansk præg.

I det hele taget forstod foretagendet at tilpasse sig de skiftende tiders krav - og der skete meget også varmeteknisk i slutningen af sidste århundrede - men vi vil her ikke komme ind på den videre udvikling, blot nøjes med at slå fast, at »Ofenfabrik des Brüderhauses Neuwied G. m. b. H.« $\mathrm{i}$ dag er et moderne foretagende, som til fulde opfylder vor tids krav, samtidig med at det bærer en mere end 200-årig tradition i sig. ${ }^{1}$

Vi skal straks se, at der består en direkte sammenhæng mellem ovnproduktionen i Neuwied og Christiansfelder-ovnene.

Christiansfeld blev grundlagt i 1772, og det er den eneste brødremenighedsby i Norden. I løbet af meget kort tid blev de nødvendige bygninger rejst, og byen fik det arkitektoniske præg, som den har bevaret nogenlunde intakt til i dag, da den står som et enestående minde over den særprægede herrnhuter-kultur.

Om tilstandene i 1779 får vi et indtryk gennem Hans Holcks beskrivelse $\mathrm{i}$ "De kongelige Rigers og Fyrstendømmers Stats- og Handels-Spejl for Aaret 1780 «. Han meddeler: "Indvaanernes meste Beskæftigelser bestaae udi Fabriquer og Haandværks-Arbeyde... 


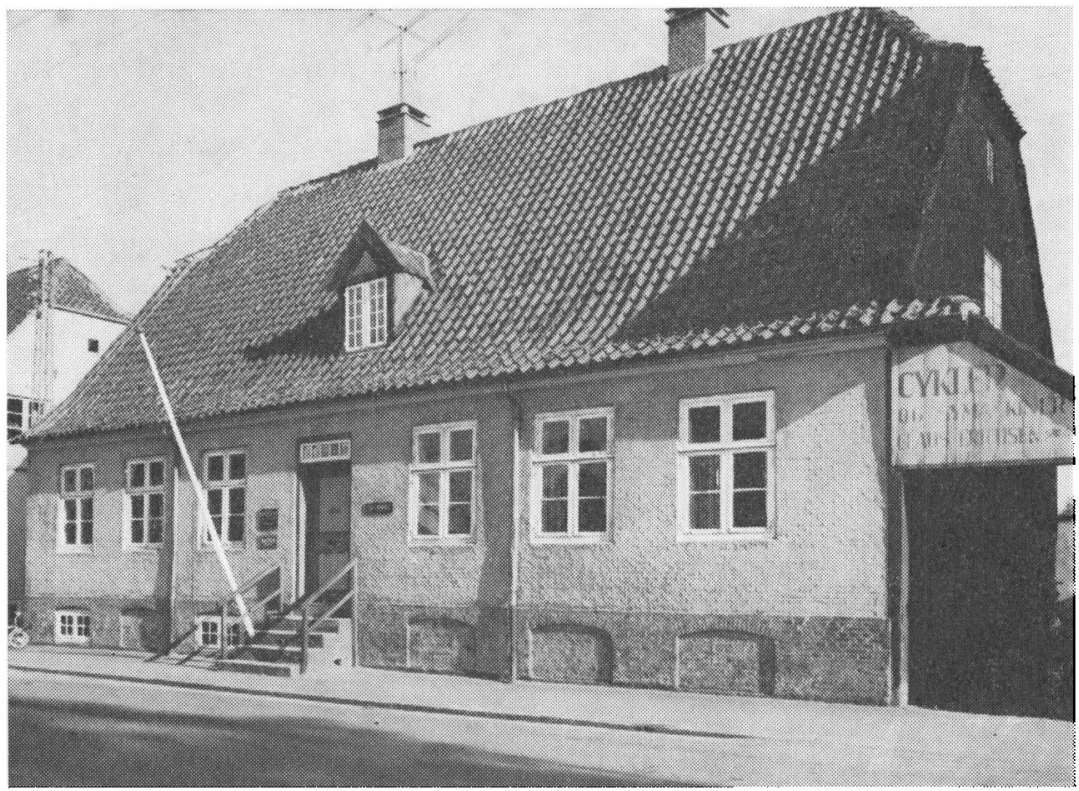

Lindegade 44 i Christiansfeld. Huset er bygget 1781 af Abraham Goll. I gården findes en yngre varkstedsbygning. Her havde pottemageriet og kakkelovnsfabrikken til huse. (Foto: Det sarlige Bygningssyn).

Iblandt de gifte Stedets Indvaanere findes som Haandværks-Mestere: en Tøymager ... en Lomme-Uhrmager, en Skoemager, en Feldbereder eller Handskemager, en Bundtmager, en Snedker, en Tømmermester, en Farver og en Pottemager, der forarbeyder de i Tydskland brugelige Leer-Træk-Ovne, for derved at spare Brændeved $\aleph^{2}{ }^{2}$

Den sidstnæunte er vor mand, og det er ingen anden end den Abraham Goll, der fra 1770 til 1777 var leder af pottemageriet i Neuwied am Rhein. Samme år, som han forsvinder fra Neuwied, dukker han op i Christiansfeld, utvivlsomt dirigeret til den nye menighed for at tage sig af dens pottemageri, der heller ikke her var et privatforetagende.

Det var således ikke et tilfældigt menighedsmedlem, men en erfaren og dygtig håndværker, der kom til den unge herrnhuterkoloni, og dermed har vi dels forklaringen på ovnenes kvalitet, dels begrundelsen for deres fremmedartede karakter. Goll har utvivlsomt haft formene med fra Neuwied. I typer og glasurer er kaklerne fra 
Neuwied og Christiansfeld hinanden så lig, at de gensidig kan supplere hinanden, og den nære kontakt med moderforetagendet bevaredes, som vi i det følgende skal se, ned gennem tiden.

Fra det nærliggende Tyrstrup fik man ler til fabrikationen. Mens modelløren formede modellerne, var det pottemagerens egentlige opgave at lave kaklerne og ovnsætterens at mure ovnene op. Hyppigt forenedes de forskellige beskæftigelser dog i samme person.

Et indblik $\mathrm{i}$ virksomheden giver de inventariefortegnelser, som menigheden lod optage, og som bevares i brødremenighedens arkiv på kirkeloftet i Christiansfeld. Her findes et læg med sådanne registreringer fra 1800, 1801 og 1858 samt for hvert år fra 1862 til 74.

Virksomheden betegnes $i$ inventariefortegnelserne fra 1800 og 1801 »Töpferei« (d.v.s. pottemageri). Det samme er tilfældet i 1858 , mens fortegnelserne for tiden fra 1862 til 1874 har betegnelsen "Gemein-Ofenfabrik und Töpferei« (d. v. s. menigheds-ovnfabrik og pottemageri).

Jeg vil her koncentrere fremstillingen om kakkelovnene, som foretagendet fortrinsvis var baseret på, og som var dets egentlige specialitet, men det må for helhedens skyld slås fast, at der jæunsides med kakkelovnsfabrikationen har fundet en omfattende forhandling og fremstilling af andre pottemagervarer sted. Det viser inventariefortegnelserne tydeligt nok.

Abraham Goll blev i Christiansfeld. 1777 giftede han sig med Marie Magdalene Neubauerin, der også var blevet indkaldt fra Tyskland, og de fik 3 døtre.

1781 byggede han det stadig eksisterende hus Lindegade 44, overfor alleen, der fører ind til kirkegården, Gudsageren.

Det fik syv fag og blev opført $i$ grundmur $i$ en etage med høj sokkel og kælder. Tegltaget fik små valme og til gaden en spids teglhængt tagkvist. Foran indgangsdøren er der en lille fritrappe. Mellem 1812 og 1878 er den nuværende sidebygning blevet opført med syv fag i grundmur. Pottemagerværkstedet med ovnen fandtes her. Sidebygningen er senere blevet noget ombygget, men endnu i 1968 bar den tydelige spor af sit oprindelige formål.

Det er et godt og typisk familiehus for en håndværker og et af de få steder i Christiansfeld, hvor der virkelig er en helhed tilbage med både forhus og værkstedsbygning. Det særlige Bygningssyn karakteriserer ejendommen som bevaringsværdig. ${ }^{3}$ 
Karakteristisk kakkelovn fra Christiansfeld, nu i Borgmestergården $i$ „Den gamle By" $i$ Arhus. Kaklerne har begitning og blyglasur med dekoration $i$ mangan. De er af en type, der mä skrive sig fra fabrikkens forste tid.

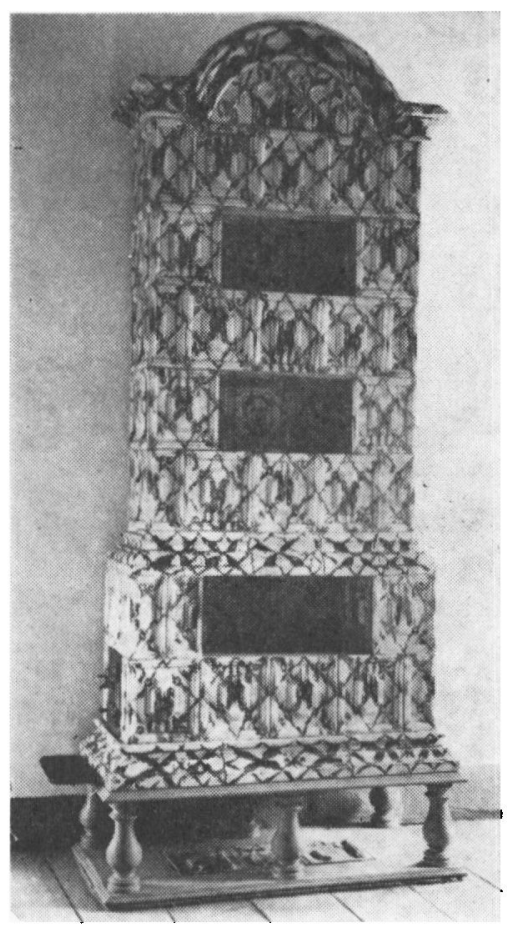

Fodstykket er af trap. Hojde ca. $2 \mathrm{~m}$.

I dette hus skulle Abraham Goll og hans efterfølgere komme til at bo, så længe der fremstilledes kakkelovne i Christiansfeld.

Abraham Goll døde 24. april 1800 og blev begravet på Gudsageren, hvor hans gravsten med nummeret 216 endnu er at se på den stemningsfulde kirkegård. I november samme år flyttede hans enke med datteren Marie Magdalene ind $i$ enkehuset, hvor hun blev boende til sin død 1806.

Efter Golls død blev der optaget et "Inventarium " over, hvad der fandtes af efterladte pottemagervarer og til faget henhørende materialer, redskaber $\mathrm{m}$. $\mathrm{m}$.

Der er i dette næunt en stor mængde kakler til ovnenes forskellige dele. Der opregnes kakler i farverne grønt, violet, paille (d.v.s. gult) og sort. En del halvfabrikata findes også. Desuden nævnes jerndele til ovnene og drejede ben og fodstykker af træ.

Endvidere opregnes et stort lager af andre pottemagervarer, del- 
vis andetsteds fra, samt de redskaber og det inventar, der hører med til et veludstyret pottemageri. F. eks. nævnes $\$ 1$ Glasur Mühle, mit Marmor Steine".

På det gode grundlag, der således var blevet lagt i Golls tid, fortsatte brødremenigheden efter hans død med at fremstille og forhandle kakler og andre pottemagervarer.

Den 12. december 1800 sluttede man kontrakt med en ny mester. Han hed Jens Aastrup og var født 4. oktober 1778 på gården Thulstrup ved Hobro. Han skulle blive efterfulgt $i$ stillingen af en søn.

Det er i Jens Aastrups tid, at rejsebeskriveren L. M. Wedel 1803 beretter om Christiansfeld: "I Fabrikkerne og Boutikerne her haves alle mulige Vare, som ere sxrdeles gode, men ogsaa noget dyrere end andetsteds, og de bestemte Priser paa enhver Ting maae en Kiøber ikke haabe at kunde forandre ved nogen Prutning. " Efter yderligere at have gjort vrøvl over priserne fortæller han: »Deres brændselsbesparende Indretninger i Bryggerierne, Bænderierne og i Kakkelovnene maa jeg ønske, at sagkyndige ville undersøge, jeg forstaaer ej at bedømme det; deres Fajance-Kakkelovne ere de skiønneste, jeg har set. $\mathrm{Og}$ ved besøget på Trolleborg skoleholderseminarium fremhæver han blandt de fortræffelige indretninger, at der sere skiønne store Kakkelovne af Christiansfeldts Fajance. «"

At han og også andre anvender ordet fajance $i$ forbindelse med Christiansfelder-ovnene, må ikke føre til den misforståelse, at der er tale om egentlige fajanceovne. Keramikken fra Christiansfeld var og blev lertøj.

Det er sandsynligt, at det er i Jens Aastrups tid, at den stadig eksisterende værkstedsbygning er blevet bygget til huset $\mathrm{i}$ Lindegade. Den findes endnu ikke på en byplan fra 1812. At virksomheden dog selv $\mathrm{i}$ Christiansfelds velmagtsdage var et beskedent foretagende, kan vi slutte af, at personalet i 1835 foruden af mester blot bestod af to svende og en daglejer.

Jens Aastrup døde 19. oktober 1838 og blev som nævnt efterfulgt af en søn, Johannes Nicolaus Aastrup, der var født 12. januar 1807, og som havde lært professionen. Fra hans tid stammer et "Inventarium «, dateret april 1858. Der opregnes i det af hele ovne grå og hvide, bl. a. en rund, hvid ovn og ovne med runde hjørner. Også en gammel riflet og en gammel marmoreret ovn er blandt dem, der nævnes. 


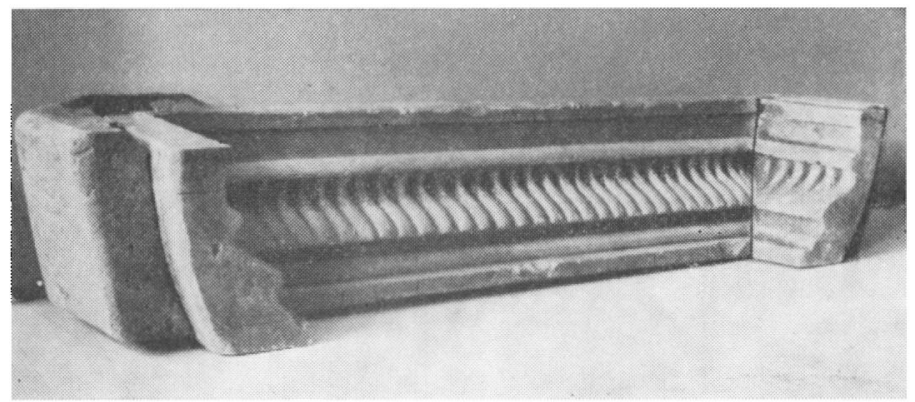

Kakkelform til gesims fra kakkelovnsfabrikken i Christiansfeld. Formen er af gips og har en los indsats $i$ hver ende. Langde ca. $75 \mathrm{~cm}$. „Den gamle By“, Arhus.

Kakkelovnene behøver dog ikke - lige så lidt som de øvrige pottemagervarer - udelukkende at være fremstillet i Christiansfeld. Senere fortegnelser viser, at man da også forhandlede ovne fra andre fabrikker.

Johannes Nicolaus Aastrup døde 23. marts 1862, og hans efterfølger blev Hans Peter Hansen. Han var født 9. oktober $1834 \mathrm{i}$ Christiansfeld, hvor hans far var murermester. Efter konfirmationen lærte han faderens håndværk, men drog 1859 til Neuwied for at blive uddannet $\mathrm{i}$ den derværende ovnfabrik, og 1862 overtog han ledelsen af pottemageriet i Christiansfeld. Hans Peter Hansens rejse til Neuwied i hundredåret for Abraham Golls ankomst til samme by er kun et af eksemplerne på den stadige kontakt med moderforetagendet. Med tråde, der ofte var usynlige for den uindviede, var de enkelte menigheder og deres medlemmer i virkeligheden knyttet sammen til et stort hele.

Hans Peter Hansens pottemagerkarriere blev dog kortvarig. Allerede 1867 drog han bort, men vendte 1868 atter tilbage og indtrådte i faderens forretning, som han senere overtog sammen med en bror. Tillige drev han stenhuggeri. Han dede 20. april 1889.

Fra hans tid nævnes i fortegnelserne hvide, grå og violette ovne. Der opregnes også gipsforme og tre kakkelforme af træ. December 1865 opgøres lageret til 2400 stk. "gebrannte Ofenwaare« og 350 stk. "rohe ditto «, otte hvide ovne, to violette og en grå.

Den mand, der trådte til, da Hans Peter Hansen i 1867 rejste 
bort, kom udefra, men var gennem sin oprindelse og uddannelse som forudbestemt til stillingen.

Han hed Julius Eugen Wünsche, og hans levnedsløb er karakteristisk for et barn af brødremenigheden.

Han var født 7. december 1841 i Paramaribo i Sydamerika, hvor hans forældre virkede $\mathrm{i}$ missionens tjeneste. Som seksårig blev han sendt $\mathrm{i}$ menighedens "Knabenanstalt « $\mathrm{i}$ Kleinwelke og kom efter sin konfirmation i lære i pottemageriet i Zeist i Holland, hvor der også fandtes en herrnhuterkoloni. Dette pottemageri kræver en nærmere omtale, da det ligesom foretagendet i Christiansfeld var en aflægger af Neuwied. Det er i den sammenhæng ganske interessant, at den mand, der startede fabrikken i Zeist, bxerer det danske navn Nörgaard.

Den 31. august 1835 oprettede E. L. Nörgaard her et værksted, hvor han begyndte at fremstille kakkelovne. Han havde tidligere været knyttet til fabrikken i Neuwied, men ønskede altså at prøve for sig selv.

Nörgaard måtte imidlertid kæmpe med store vanskeligheder, men det lykkedes ham dog at skaffe sine ovne indpas og at holde bedriften $i$ gang til sin død fem år efter. Kakkelovnene havde da vundet et godt ry, og menigheden besluttede at redde foretagendet. $\mathrm{Og}$ redningen kom fra Neuwied, idet man fik selve lederen af kakkelovnsfabrikken, Ernst Christoph Martin, til at rejse til Zeist, ligesom i sin tid Abraham Goll var draget til Christiansfeld. 1840 overtog han ledelsen af fabrikken, og ikke mindst takket være hans indsats blev Zeister-kakkelovne kendt vidt omkring.

Hans efterkommere fortsatte virksomheden, og den blev først ophævet i slutningen af $1950 \mathrm{erne}$, men var da baseret på fremstillingen af andet keramik. Det kan ikke undre, at bevarede ovne og billeder fra Martins tid viser stor lighed med ovnene i Neuwied og Christiansfeld. ${ }^{5}$ De tre fabrikker er så nøje forbundet, at man for at forstå en af dem, uundgåeligt må drage de to andre med ind $\mathrm{i}$ billedet.

Det var således en god skole, Wünsche havde gået $\mathrm{i}$. Han blev $\mathrm{i}$ Zeist i syv år, arbejdede derpå som svend andetsteds og blev i oktober 1867 opfordret til at overtage ledelsen af pottemageriet $i$ Christiansfeld.

Her skulle han blive resten af sit liv. 1875 giftede han sig med en missionærdatter, der var født på Grønland, og de fik deres hjem i huset i Lindegade. 
Kulikel af den sidste type, der blev fremstillet $i$ Christiansfeld $i$,alt-deutsch" stil med brun glasur.

Hojde $\mathrm{ca} .21 \mathrm{~cm}$.

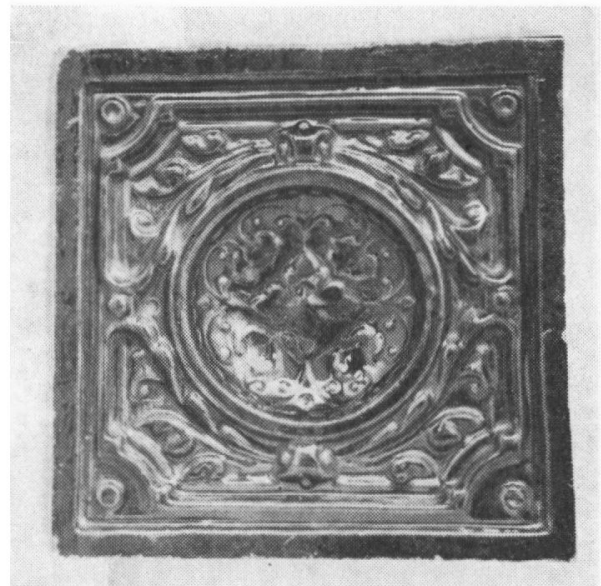

„Den gamle By“, Arhus.

Det var da blevet kritiske tider for erhvervslivet i Christiansfeld. Opgangstiden var forlæengst forbi, og stadig flere af menighedsforetagenderne afvikledes.

I opgørelsen for 1872 opregnes af hele ovne to halvhvide, fire grå, hvoraf tre hidrører fra forgengeren, Hansen, en blå, en ovn fra Altona, en fra Strassbourg og to fra Kellinghusen samt talrige løsdele, af hvilke også en del kommer udefra. Fra Wünsches tid kendes endvidere en »Regulierofen " samt »Begussöfen «.

Med 1874 ophører fortegnelserne i arkivet i Christiansfeld. 1875 solgtes kakkelovnsfabrikken og pottemageriet nemlig til Julius Eugen Wünsche, der ved en kontrakt dateret 19. januar 1875 købte det hidtil for brødremenighedens regning drevne foretagende. Købesummen androg 4403 Mark $13 \mathrm{Pf}$. Selve ejendommen blev dog ved med at tilhøre brødremenigheden.

Det blev svære tider, der forestod for familien i Lindegade 44, hvor der efterhånden kom otte børn. Julius Eugen Wünsches søn og efterfølger fortæller derom i sit levnedsløb, d. v.s. den korte biografi, som ethvert medlem af menigheden opfordres til at skrive. Han beretter (i oversættelse): "Med kassen forholdt det sig sådan, som jeg endnu kan høre min kxre far sige: "Jeg siger vel ikke for meget, når jeg siger, at vi er vel hundrede gange stået op uden at have så meget som en pfennig $\mathrm{i}$ kassen. « Gxlden hos købmand og skomager lod sig ikke mere afdrage, og disse og andre bekymringer 


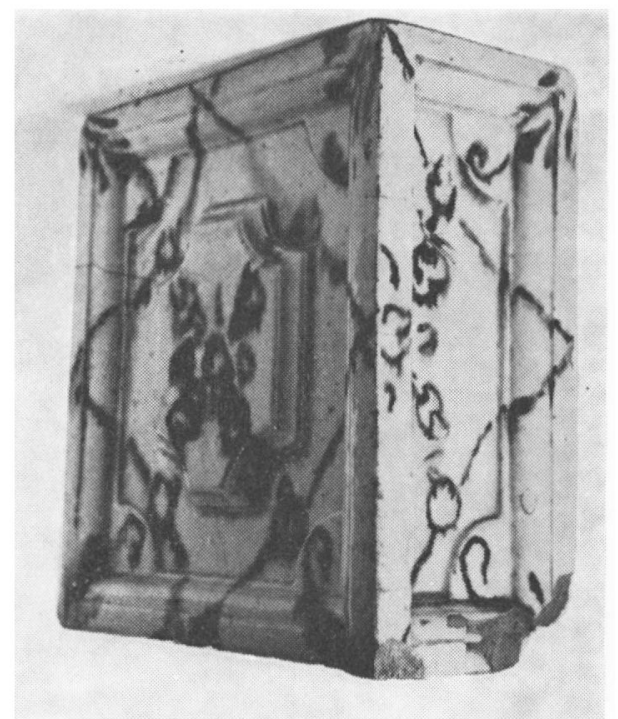

Hjornekakkel af baroktype med begitning og blyglasur med dekoration i mangan. Hojde ca. $21 \mathrm{~cm}$. „Den gamle By“, Arhus.

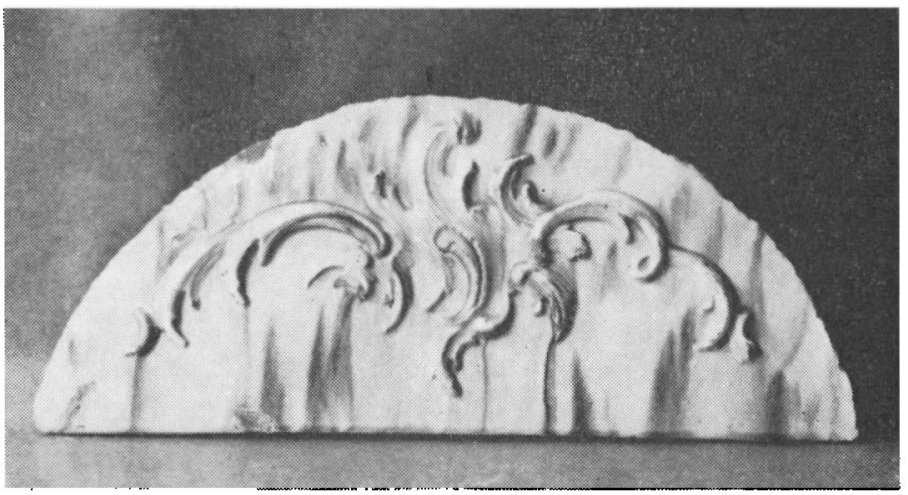

Topstykke med rokoko-dekoration og begitning og blyglasur med gron marmorering. Hojde ca. $15 \mathrm{~cm}$. "Den gamle By", Arhus.

trykkede uophørligt min far. Min mor havde den ikke lette opgave at sørge for maden, for som hun sagde: "Der skal være meget, det skal være godt, og det må ikke koste noget.««

Tiden var løbet fra virksomheden. Vel forsøgte man at imøde- 
Christiansfelderovn $i$ ovnsamlingen. $i$,Den gamle By" $i$ Arhus. Biedemeier, kaklerne har stenket, lys brunviolet glasur. Trafodsstykke. Hojde ca. $228 \mathrm{~cm}$.

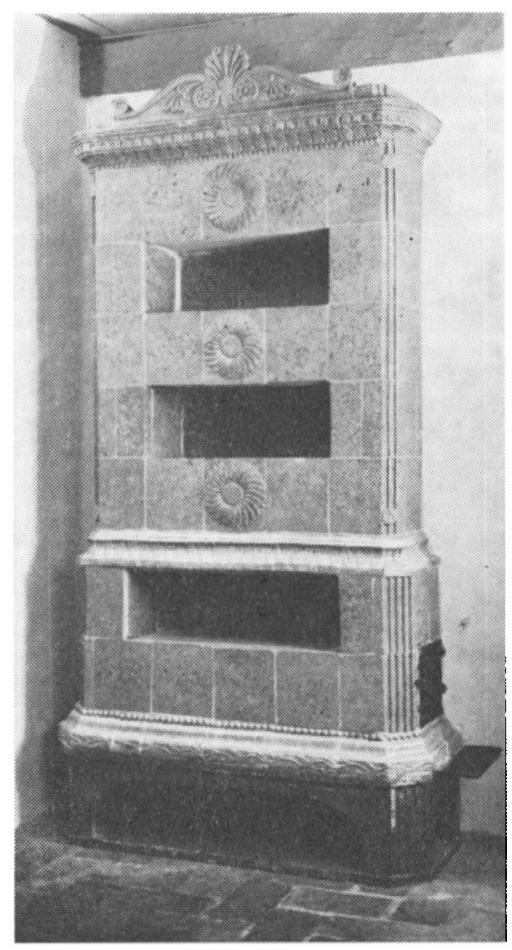

komme den moderne smag med kakler $\mathrm{i}$ ralt-deutsch « stil, d. v. s. i nyrenæssance med relief og farvet glasur, men de blev unægtelig både vinde og skxve, og ifølge traditionen blev den sidste kakkelovn lavet i Christiansfeld i 1898.

Men der var stadig noget arbejde med at sxtte de gamle ovne om og sætte de nye op, der nu udelukkende kom udefra. På den tid fandtes der i Tyskland flere store kakkelovnsfabrikker, der leverede nogle yderst perfekte og elegante fajanceovne, som opfyldte alle modens krav. Herhjemme kender man dem fra xldre lejligheder med herskabelige prætentioner. De benævnes ofte porcelænsovne.

I 1889 begyndte Wünsche tillige en gravstensforretning. Han havde som ung lært faget $i$ halvandet år. Forøvrigt havde moderforetagendet i Neuwied også givet sig af dermed, og i Christiansfeld havde forgængeren Hans Peter Hansen drevet en sådan.

Pottemageriet ophørte dog ikke ganske. Jxunsides med kakkel- 


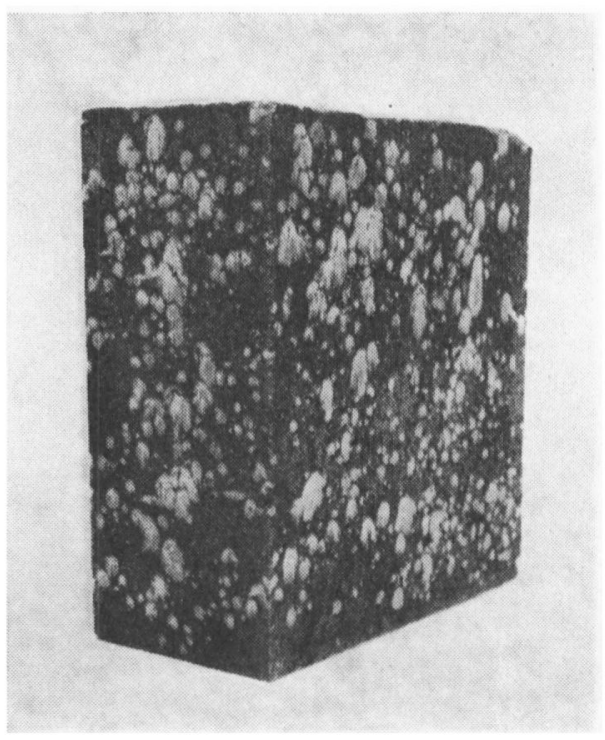

Hiornekakkel med glasur stenket med mangan og hvidt. Hojde $\mathrm{ca} .21 \mathrm{~cm}$. „Den gamle By", Arhus.

ovnsfabrikationen havde der jo hele tiden fundet salg og fremstilling af andre pottemagervarer sted. Folk kan endnu huske, at de fandtes udstillede $\mathrm{i}$ den overdxkkede port $\mathrm{i}$ huset $\mathrm{i}$ Lindegade.

1907 overdrog J. E. Wünsche forretningen til sin søn, Carl Theodor Wünsche. Wünsche senior døde 27. september 1917.

C. T. Wünsche fortsatte som ovnsætter og stenhugger. Han var født 16. marts $1880 \mathrm{og}$ kom straks efter sin konfirmation i lære hos faderen. Han lxgger i sit levnedsløb ikke skjul på, at det snavsede ovnsxtterfag alle dage var ham en plage, mens han var glad for arbejdet med gravstenene. Fra sin læretid fortæller han (i oversættelse): "Opsxtningen af ovne ude på landet var altid surt, og mange gange har jeg ladet mine tårer løbe på ensomme veje. Cykler var ikke almindelige. Med dagvognen rejste jeg til gårdens nærhed og gik så til fods. Jeg kunne ikke føle mig hjemme hos de fremmede folk og sagde næppe et ord. Jeg var først lykkelig, når arbejdet var færdigt, og det atter gik hjemad «.

Carl Theodor Wünsche var 27 år, da han overtog faderens forretning. Under forste verdenskrig var han indkaldt. 1919 giftede han sig med en missionærdatter, der var født i Sydamerika, og familien kom til at bo $\mathrm{i}$ huset $\mathrm{i}$ Lindegade 44. 
$P_{a}^{\circ}$ Wünsches tid var de gamle Christiansfelder-ovne for alvor ved at blive påskønnede antikviteter, og skulle en af dem sættes op, måtte man have fat $\mathrm{i}$ Wünsche, der $\mathrm{i}$ sig bevarede hele den gamle håndværkstradition. Han døde 2. juni 1960.

Den sidste ovnsætter i Christiansfeld er Karl Waldemar Schmidt. Han er født i Christiansfeld 26. oktober 1905 af gammel herrnhuterfamilie. I 1921 begyndte han sin lxretid i herrnhuterkolonien Neusalz an der Oder og kom 1925 til Neuwied am Rhein for at arbejde $\mathrm{i}$ Ofenfabrik des Brüderhauses, hvorfra som omtalt Abraham Goll i sin tid var udgået.

1931 påbegyndte Schmidt sin forretning i Christiansfeld, hvor han blev og stiftede familie, og da Wünsche døde i 1960, overtog han hans lager.

Med ovnsætterfaget er det nu ved at være definitivt forbi. Opsættes der end i ny og næ en af de gamle ovne, så forsvinder der stadig flere fra deres oprindelige pladser. I Christiansfeld har indlægningen af fjernvarme $i$ de senere år fort til en stærk formindskelse af antallet af kakkelovne. De har som pladsrøvende monumenter over fortidens opvarmning måttet vige for nutidens krav til rationel boligindretning. De, der bliver stående, kan dog gøre god nytte ved ventilering af stuerne.

Det er især de tidlige kakkelovne og kakler fra Christiansfeld, som har et iøjnefaldende sxrpræg, og da de kom til at danne grundlaget for den senere produktion, vil vi i det folgende betragte nogle af dem.

Typiske er kaklerne med begitning og blygasur. Ved begitning forstås overtrækning af kaklerne med et tyndt lag pibeler før glaseringen, så de fremtræeder lysegule under den klare glasur. De kan være udekorerede, men har ofte en marmorering i grønt eller manganviolet. Farverne er hyppigt løbet ud under brændingen. Denne glasur findes på kakler i stilarterne barok, rokoko, Louis-XVI og empire.

En meget udbredt type har barokform med kraftig ramme- og fyldingsdekoration $i$ relief. Ofte er ovne med sådanne kakler afsluttet af et rundbuet topstykke med rokokoornamentik og gesims. Almindeligvis er fodstykkerne af træ.

Indtagende er Louis-XVI-kaklerne med et ovalt riflet felt omgivet af en perlebort. Man kender også andre former for rifling, og nogle 
kakler har en kantet ramme- og fyldingsdekoration i fladt relief. Det er empiretidens udgave af de kraftigt formede barokkakler. En ovn af disse kakler med mørkebrun glasur kendes også. Der findes endvidere talrige kakler med finere eller grovere stænket glasur. De kan være spættet i manganviolet og hvidt eller fremtræde blegviolette eller lyst gråbrune. En svag grønlig tone kan give glasuren et særligt spil.

Det er på en sådan manganstænket kakkel, at Abraham Goll engang har ridset sit navn $\mathrm{i}$ kanten $\mathrm{i}$ det endnu bløde ler. Ovnsættermester Schmidt fandt den tilfældigvis for flere år siden mellem andre kakler og indsatte den $i$ en ovn i den villa $i$ Haderslev, hvor nu amtsvejvæsenet har til huse.

Foruden de almindelige kakler er der bl. a. hjørnekakler, topstykker, gesimsstykker og kakler i gennembrudt arbejde. Alle disse forskellige stykker kan være smykkede med relieffer. Især Biedermeier-ovnene frembyder en meget stor variation af smagfulde plastiske ornamenter, der ligger meget nær op ad sådanne fra Neuwied og Zeist.

Kakkelovnene kunne opmures efter behov i hvilken højde, man ønskede det, og ikke mindst de høje, velproportionerede etageovne besidder en monumentalitet, der harmonerer smukt med byggesættet $i$ herrnhuterbyen.

De $x$ ldre ovnes træfodstykker kan have drejede eller glatte ben; senere træffer vi jernstativer, der kan være skjult af plastiske dyreben af keramik.

Etagedelingen af ovnene skulle tjene til en bedre udnyttelse af brændslet, idet varmen blev ledt i siksak igennem dem. De fik derved også en større varmegivende overflade, og de åbne mellemrum mellem etagerne kunne bruges til at holde maden varm. Fra tidens jernovne kender vi en tilsvarende opbygning. Mens de ældre ovne var beregnet til brænde, måtte ovnene, da kul og koks kom almindeligt $\mathrm{i}$ brug $\mathrm{i}$ sidste århundrede, indrettes dertil. De senere ovne er derfor ofte forsynet med kasser af støbejern.

Vi kender også de hvidlige ovne med reliefdekorationer fra Christiansfeld. Deres glasur er mere mat og grålig end på de virtuose eksemplarer, der kom fra de store tyske fabrikker. Man kunne i pottemageriet i Christiansfeld slet ikke frembringe de høje varmegrader, der var nødvendige for at fremstille egentlige fajanceovne. 
Virksomheden i Christiansfeld beholdt hele tiden håndværkets karakter og endte - som vi har set - med at være et meget beskedent foretagende.

I Abraham Golls hus i Lindegade, hvor så mange af hans efterfølgere kom til at bo, lever der ikke mere pottemagere, men endnu kan man på loftet i værkstedsbygningen finde kakler, forme og redskaber, som hidrører fra den gamle kakkelovnsfabrik.

Med sine tråde til moderforetagendet i Neuwied am Rhein og søsterforetagendet i Zeist er virksomheden i Christiansfeld et karakteristisk eksempel på menighedens nøje indre sammenhæng og hele internationale karakter.

Det gælder også for mestrene, der alle har tilhørt brødremenigheden og undertiden fra fjerne egne er blevet dirigeret til den lille sønderjyske by, hvor de kom til at øve deres livsgerning.

\section{NOTER OG HENVISNINGER}

1. Dieter Krieg: Das Brüderhaus und die Töpferei im Hernnhuter Viertel, artikel i Heimatkalender des Kreises Neuwied 1958.

Ofenfabrik des Brüderhauses Neuwied G.m.b.H. 1758-1958, publikation i anledning af virksomhedens 200-års jubilæum.

2. Hans Holck: De Kongelige Rigers og Fyrstendømmers Stats- og Handels-Spejl for Aaret 1780 , s. 418 .

3. Det særlige Bygningssyns sekretariat: Bevaringsplan Christiansfeld, Kbh. 1966, s. 21.

4. L. M. Wedel: Indenlandsk Reise, I, 2, Kbh. 1803, s. 109-111 og I, 1, Kbh. 1803 , s. 57.

5. B. Dubbe: De kacheloven, Lochem 1966, s. 51-55.

Oplysningerne om mestrene og virksomheden hidrører overvejende fra tilførsler til kirkebogen i Christiansfeld samt fra levnedsløb, inventariefortegnelser og andre arkivalier $\mathrm{i}$ brødremenighedens arkiv $\mathrm{i}$ Christiansfeld, suppleret med mundtlige meddelelser.

Emnet er tidligere blevet behandlet af forfatteren til nærværende artikel i -Den gamle By«s årbog 1967. Der er dog her blevet inddraget nyt stof, isæer med hensyn til forbindelserne mellem herrnhuterkolonierne, ligesom det stof, der specielt angår købstadmuseet $*$ Den gamle By*, er udeladt. 